\title{
Korkeakoulutuksen rakenteiden pitäisi tukea aikuiskoulutusta
}

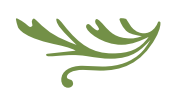

\author{
Korkeasti koulutetut hankkivat jatko- ja täydennyskoulutusta \\ usein maksuttoman peruskoulutuksen tarjonnasta. Se vähentää \\ ensimmäiseen tutkintoon pyrkivien aloituspaikkoja ja samalla hidastaa \\ jatkokoulutustarjonnan kehittymistä.
}

NYKYINEN HALLITUS on esittänyt tavoitteekseen talouden kilpailukykyä luovan korkeatasoisen osaamisen varmistamisen ja Suomen nostamisen kaikilla osaamisen kriteereillä OECD-maiden kärkeen. Tämä on haastava tavoite, joka edellyttää perinteisten koulutusratkaisujen kriittistä tarkastelua. Aikuiskoulutuksen näkökulmasta tavoitteet tarkoittavat huomion kiinnittämistä myös hyvän peruskoulutuksen saaneiden ammattilaisten ja asiantuntijatehtävissä toimivien osaamisen kehittämiseen. Tavoitteet ovat erityisen kunnianhimoisia, kun otetaan huomioon samanaikaisesti ratkaistavana oleva julkisen talouden kestävyysvaje. Tämän seurauksena ei ole realistista ajatella, että aikuiskoulutukseen voitaisiin suunnata merkittävästi nykyistä enemmän julkista rahoitusta.
Viime vuosien aikana suomalaisten koulutustason kehitys on ollut suhteellisen hidasta moneen muuhun korkean koulutustason maahan verrattuna (OECD, 2012). Tältä osin hallitusohjelman tavoite näyttää karkaavan käsistä, ellei koulutukseen osallistumiseen saada uudenlaista dynamiikkaa. Sama koskee myös sukupolvien välisiä eroja. Nuoremmat ikäluokat ovat selvästi vanhempia ikäluokkia koulutetumpia, ja myös aikuiskoulutukseen osallistuminen painottuu nuorempiin ikäluokkiin.

Korkea-asteen koulutuspaikkoja on tarjolla noin 70 \%:lle ikäluokkasta, ja eräissä maakunnissa paikoin jopa yli. Tällä hetkellä 30- vuotiaista noin $30 \%$ :1la on korkea-asteen tutkinto. Korkeakoulutetun väestön määrä on kasvanut nopeasti viimevuosikymmeninä. Työelämässä korkeakoulutetut toimivat mer- 
kittävissä asiantuntijatehtävissä ja suomalaisen yhteiskunnan muuntumiskyky ja mahdollisuus vastata globalisaation, teknologisen muutoksen ja kestävän kehityksen haasteisiin riippuu paljolti tämän korkeasti koulutetun väestönosan osaamisen tasosta (Lehtinen ym. 2012).

\section{KUINKA KORKEASTI KOULUTETTUJEN OSAAMISTA YLLÄPIDETÄÄN?}

Erityisesti yliopistojen tiedeperustaisen koulutuksen on ajateltu antavan alemman koulutusasteen tutkintoihin verrattuna syvällisemmän ymmärryksen sekä paremmat ajattelun ja tiedonkäsittelyn valmiudet. Korkeakoulutettujen elinikäisen oppimisen toteutumista ei ole aiemmin nähty ongelmana, koska korkeakoulutuksessa hankittujen valmiuksien on katsottu kantavan läpi koko työuran. On pidetty ikään kuin itsestään selvänä, että akateemisesti koulutettujen asiantuntijoiden osaaminen vahvistuu ja uudistuu osana normaalia työkokemusta ja että he päivittävät osaamistaan tarpeen mukaan.

Sekä käytännön kokemus että asiantuntijuustutkimuksen empiiriset löydökset osoittavat tämän uskomuksen vääräksi. Ensinnäkin muutokset organisaatioissa, teknologioissa ja toimintakäytännöissä ovat usein niin suuria, että niiden hallitseminen ja vaadittavan asiantuntijuuden uudistaminen itsenäisesti päivittäisten rutiinien ohessa on liian vaativa tehtävä yksittäiselle työntekijälle. Maailman johtavana asiantuntijuuden tutkijana pidetty Anders Ericsson on empiirisiin havaintoihin pohjautuen esittänyt, että edes aiemmin saavutettua osaamisen tasoa ei välttämättä pysty säilyttämään, kun kokemusta kartutetaan päivittäisiä rutiineja toistamalla. Lääkäreiden elinikäisen asiantuntijuuden kehittymistä tutkiessaan hän pätyi hämmentävään johtopäätökseen: paras ennustaja läkäreiden epäpätevyydelle on työvuosien määrä. Tämä ei ole ikää koskeva kommentti, vaan viittaa siihen, että asiantuntijuuttaan ylläpitämiseksi ja kehittämiseksi lääkäreiden on tarkoituksellisesti kehitettävä tietojaan ja taitojaan ja tähän ei päivittäisten diagnoosi- ja hoitorutiineiden toistaminen riitä, tekee sitä kuinka paljon hyvänsä (Ericsson, Charnes, Feltovich \& Hoffman 2006).

Eräillä aloilla on jo pitkään ollut hyvin organi- soituja ja alan piirissä vahvaa arvostusta nauttivia ammatillisen jatkokoulutuksen malleja, joiden tavoitteena on korkeakoulutettujen työntekijöiden osaamisen syventäminen ja siihen liittyvä erikoistuminen erityisen vaativiin tehtäviin. Tunnetuimpia ovat esimerkiksi erikoislääkäritutkinto, asianajajatutkinto ja vakuutusalan aktuaaritutkinto. Korkeakoulujärjestelmän näkökulmasta on yllättävää havaita, että valtaosa näistä akateemisten asiantuntijoiden ammatillisen jatkokouluttautumisen muodoista on syntynyt ja edelleen toimii yliopistojen ulkopuolella. Koulutuksesta, osaamisvaatimusten määrittelystä, kuulusteluista ja nimikkeiden myöntämisestä vastaavat työelämän omat organisaatiot- tosin monissa tapauksissa yhteistyössä sektoriministeriöiden kanssa. Osa malleista, kuten lääkäreiden erikoistuminen, on sittemmin liitetty yliopistojen tehtäväksi.

Koulutusjärjestelmän toimivuuden arvioinnin kannalta on merkittävää, että monilla akateemiseen koulutukseen perustuvilla aloilla ei ole minkäänlaista vakiintunutta ammatillisen jatkokoukutuksen järjestelmää. Tällaisia ovat esimerkiksi opettajan ammatti sekä ammatit joissa ei ole suoraa yhteyttä tietyn korkeakoulututkinnon ja tehtävänimikkeiden välillä. On kuitenkin selvää, että näilläkin aloilla on lisääntyvässä määrin erityisiä tehtäviä, joihin korkeakoulujen perustutkinnot eivät sellaisenaan riitä, vaan tarvittavan pätevyyden saavuttaminen edellyttäisi systemaattisia lisäopintoja ja erityisosaamisen osoittamista. Tähän tarpeeseen vastaavia työntekijöiden ja työnantajien arvostamia koulutusmalleja ja nimikkeitä ei kuitenkaan ole syntynyt.

Lisähaasteen korkeakoulutettujen ammatilliselle jatkokoulutukselle aiheuttaa se, että globaalit, yhteiskunnalliset ja teknologiset muutokset ovat luoneet kokonaan uudenlaisia asiantuntijuuden aloja ja työtehtäviä. Koulutusjärjestelmä ja perustutkinnot reagoivat usein vasta pitkällä viiveellä näihin uusiin osaamisen tarpeisiin.

Kaiken kaikkiaan viimevuosina lisäkoulutuksen tarve on kasvanut. Tähän on vastattu ennen kaikkea työelämän sisäisellä henkilöstökoulutuksella. Työpaikan henkilöstökoulutukseen osallistuminen ei kuitenkaan ole tasaista, vaan koulutus kasautuu osal- 
le työntekijöistä ja osa korkeastikin koulutetuista on henkilöstökoulutuksen marginaalissa (Silvennoinen \& Nori 2012). Korkeakoulutettujen asiantuntijoiden kestävien työurien näkökulmasta henkilöstökoulutuksen tärkeä rajoitus on siinä, että se kohdistuu yleensä välittömään tämänhetkisen työpaikan osaamistarpeisiin vastaamiseen. Näin ollen se ei vahvista yleisemmin yksilön asiantuntijuutta ja nykyisestä työnantajasta riippumattomia pitkän aikavälin työllistymismahdollisuuksia. Tämä on erityisen vakava ongelma, sillä työelämää leimaavat nopeat rakenteelliset muutokset, ja pitkä yhtenäinen työura saman työnantajan palveluksessa on käymässä yhä harvinaisemmaksi.

\section{KORKEAKOULUTUKSEN RAKENTEELLISET ONGELMAT}

Suuri osa korkeakoulutettujen kouluttautumiskysynnästä kohdistuu myös julkiseen korkeakoulujärjestelmään. Näyttää kuitenkin siltä, että erityiset jatko- ja täydennyskoulutukseen kohdistetut kurssit ja koulutusohjelmat ovat vastanneet vain pieneen osaan tätä kysyntää. Samaan aikaan, kun yliopistokoulutuksen saaneiden työntekijöiden määrä on nopeasti kasvanut ja edellä kuvatut osaamishaasteet lisääntyneet, on yliopistojen täydennyskoulutuksen volyymi selvästi laskenut siten, että vuonna 2009 täydennyskoulutukseen osallistui enää puolet vuoden 1998 osallistujamäärästä (KOTA tilastot 1996-2009).

Varsin suuri osa korkeakoulutettujen täydennyskoulutuksen kysynnästä onkin kohdistunut yliopistojen ja ammattikorkeakoulujen perustutkintokoulutukseen. Parempaa työmarkkina-asemaa tai lisäasiantuntijuutta haetaan suorittamalla aiemman tutkinnon lisäksi muita korkeakoulututkintoja tai pyrkimällä tutkinto-opiskelijaksi sen vuoksi, että voi valita perustutkintokoulutuksesta sellaisia moduuleita, jotka vastaavat koettuun täydennyskoulutustarpeeseen. Tämä näkyy korkeakouluihin pyrkijöiden suurina märinä. Ne ylittävät selvästi ikäluokkien koon, ja huomattavalla osalla korkeakoulupaikan saaneista opiskelijoista on jo korkeakoulututkinto tai opinto-oikeus toiseen korkeakoulututkintoon.

Vuonna 2007 aiemman korkea-asteen tutkinnon oli suorittanut $15 \%$ uusista yliopisto-opiskelijoista ja koko opiskelijamäärästä $22 \%$. Aiemman tutkinnon suorittaneiden määrä on lisäksi ripeässä kasvussa (Kumpulainen 2009). Niiden osuus, joilla on opinto-oikeus myös muussa tutkinnossa, on vielä korkeampi. Tämän seurauksena huomattava määrä ensimmäiseen tutkintoonsa hakevista nuorista ylioppilaista (5 000-6 000 nuorta) jää kokonaan korkeakoulutuksen ulkopuolelle.

Rajoittamaton ilmainen opiskeluoikeus oli alun perin tärkeä osa koulutukselliseen tasa-arvoon tähtäävää koulutuspolitiikkaa. Tällä hetkellä näyttää kuitenkin siltä, että tästä periaatteesta on tullut merkittävä koulutuksellista eriarvoisuutta aiheuttava tekijä.

\section{UUTTA DYNAMIIKKAA JATKO- JA TÄYDENNYSKOULUTUKSEEN}

Olemme viimeaikaisissa raporteissamme analysoineet laajasti eri maiden aikuiskoulutuksen järjestelmiä ja Suomen nykyisen aikuiskoulutusjärjestelmän epäkohtia. Näiden analyysien pohjalta olemme luonnostelleet joukon ehdotuksia, joilla tavoitellaan uudenlaista dynamiikkaa korkeakoulutettujen ammatilliseen jatko- ja täydennyskoulutukseen. (Lehtinen ym. 2012; Lehtinen \& Mielityinen 2012a; Lehtinen \& Mielityinen 2012b).

Ehkä monelle yllättävin ehdotuksemme koskee tutkintojen asemaa. Yksi kansainvälisten mallien vertailun havaintoja oli, että Suomessa tutkinnon tiukka kytkentä maksuttomaan opiskeluoikeuteen aiheuttaa monia ongelmia ja rajoittaa korkeakoulutettujen jatko- ja täydennyskoulutuksen tarkoituksenmukaista järjestämistä. Siksi tutkinnon määrittely ja opiskelijalle maksuttoman koulutuksen määrittely tulisi erottaa toisistaan. Tutkintokoulutus voisi siis olla markkinahintaista tai koulutuspoliittisin perustein osittain tai kokonaan julkisista varoista subventoitua. Tämän jälkeen on erikseen määriteltävä, miten laajan maksuttoman opiskeluoikeuden yhteiskunta haluaa tarjota opiskelijalle (esim. Suomen tai EU-alueen kansalaisella on oikeus suorittaa maksutta yksi alempi ja ylempi yliopistotutkinto tai yksi ammattikorkeakoulututkinto ja ylempi AMK-tutkinto tai yliopiston maisteriohjelma). (Lehtinen ym. 2012)

Uudistus vapauttaisi tuhansittain opiskelupaik- 
koja ensimmäiseen tutkintoon pyrkiville ja samalla avaisi tutkinnot asiantuntijuuden syventämiseen tähtäävän jatko- ja täydennyskoulutuksen käyttöön. Erityisesti erilliset maisteriohjelmat soveltuisivat erinomaisesti ammatillisen jatkokoulutuksen tarpeisiin. Ohjelmia voitaisiin toteuttaa kansainvälisten mallien mukaisesti joustavina malleina (executive master) siten, että ne soveltuisivat hyvin työn ohessa suoritettaviksi.

Tämän periaatteellisen uudistuksen kautta myös parhaillaan opetus- ja kulttuuriministeriön työryhmässä suunniteltavat korkeakoulujen ammatilliseen jatkokoulutukseen tarkoitetut erikoistumiskoulutukset (n. 60 opintopisteen kokonaisuudet) voitaisiin liittää osaksi tutkintojärjestelmää. Tämä on tärkeää sen vuoksi, että epämääräiset tutkintojärjestelmästä irralliset opintokokonaisuudet, esimerkiksi yliopistojen täydennyskoulutuskeskusten tarjoamat PD-opinnot, eivät ole saaneet tunnustettua asemaa.

Pelkkä säädösten tarjoama mahdollisuus korkeatasoisten ammatillista jatko- ja täydennyskoulutusta palvelevien opintokokonaisuuksien ja tutkintojen tarjoamiseen ei riitä, vaan tarvitaan myös rahoitusmalli, joka luo näille opinnoille maksukykyisen kysynnän. On selvää, että suoraan valtion budjetista ei ole odotettavissa olennaista lisäystä aikuiskoulutuksen rahoitukseen, vaan korkeakoulutettujen jatko- ja täydennyskoulutuksen tulee nojata rahoituspohjan laajentamiseen niihin, jotka koulutuksesta hyötyvät.

Koulutuksen taloustieteelliset tutkimukset ovat osoittaneet, että koulutus tuottaa merkittävää taloudellista etua yksilöille ja työn tuottavuuden kasvun myötä työnantajille. Vaikka on ilmeistä, että perinteiset tutkinnot eivät tuota samalla tavalla vakaata työuraa kuin ennen (ks. Lehikoinen, Saariaho \& Suikkanen 2003), käy kansainvälisissä vertailuissa ilmi, että Suomessa koulutuksen taloudelliset tuotot ovat säilyneet korkealla tasolla (Lehtinen 2004).
Myös viimeisimmät OECD:n selvitykset (OECD, 2012) viittaavat koulutuksen yhteiskunnallisen ja yksilöllisen tuottoasteen säilyneen korkeana. Vaikka myös korkeasti koulutettuja on työttömänä, on heidän työttömyysasteensa noin puolet alemman koulutuksen saaneiden työttömyysasteesta. Myös työnantajat ovat selviä hyötyjiä osaamistason kohoamisesta.

Työntekijät ja työnantajat eivät kuitenkaan näe jatko- ja täydennyskoulutusta riittävän selkeästi investointina. Tämä on rajoittanut jatkokoulutustarjonnan kysyntälähtöistä kehittymistä ja johtanut maksuttoman peruskoulutuksen (tai koulutuksen osien) epätarkoituksenmukaiseen käyttöön täydennyskoulutuksen väylänä. Samasta syystä koulutuksen tarjoajat eivät ole kehittäneet tarkoituksenmukaisella tavalla suunnitelmallista ja pitkäkestoista täydennyskouluttautumista tukevia ohjelmia, vaan esimerkiksi korkeakoulujen täydennyskoulutuksesta vastaavien organisaatioiden toiminta on projektivetoista ja liian riippuvaista kulloinkin saatavissa olevasta ulkopuolisesta projektirahoituksesta.

Selvityshenkilöraportissamme (Lehtinen \& Mielityinen, 2012) esitämme uudenlaista jaettuun vastuuseen perustuvaa aikuiskoulutuksen rahoituksen mallia, jossa valtiovallan tehtävänä on luoda kannustimet yksilöiden ja myöhemmin myös työnantajien osallistumiselle jatko- ja täydennyskoulutuksen kustannuksiin. Yksilölliset koulutustilit perustuvat yksilön omaan säästämiseen ja valtion vastinrahoitukseen. Järjestelmää täydentäisi malli, jossa työnantajat osallistuvat kollektiivisesti koulutustilien tukemiseen. Tällöin työnantajien tuki ei ole riippuvainen työsuhteesta tai yksittäisen työnantajan halukkuudesta tukea ammatillista kehittymistä. Yksilöt voisivat käyttää tilille kertynyttä rahaa julkisen koulutusjärjestelmän tarjoaman maksullisen jatko- ja täydennyskoulutuksen koulutusmaksuihin. Koulutustilit lisäisivät aikuiskoulutuksen pitkäjänteisyyttä ja suunnitelmallisuutta. Arvioim- 
me, että koulutustilien kautta syntyvät kysyntä ja rahavirta saisi yliopistot ja ammattikorkeakoulut ja myös keskiasteen ammatilliset oppilaitokset kehittämään uudenlaisia nykyisiä ratkaisuja paremmin työelämän osaamistarpeita palvelevia koulutus- ja opiskelukokonaisuuksia.

\section{LOPUKSI}

Osaamisen ylläpitäminen ja työelämän muutoksiin vastaavan uudenlaisen asiantuntijuuden kehittäminen eivät tällä hetkellä toteudu tarkoituksenmukaisella tavalla eivätkä korkeakoulutuksen rakenteet ja rahoitusmallit ole riittäviä vastaamaan tulevaisuuden haasteisiin. Tarvitsemme uudenlaista aikuisten kouluttautumisen kulttuuria sekä sitä tukevia koulutusrakenteita ja rahoitusmalleja.

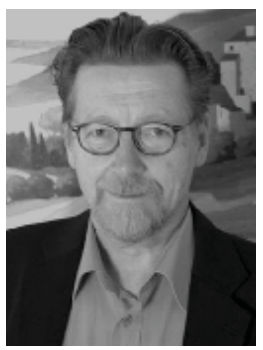

Erno Lehtinen

kasvatustieteen professori, akatemiaprofessori Oppimistutkimuksen keskus Turun yliopisto

\section{LÄHTEET}

Ericsson, K. A., Charness, P. J., Feltovich, P. J., \& Hoffmann, R. R. (Eds.). (2006). The Cambridge handbook of expertise and expert performance. Cambridge: Cambridge University Press.

Kumpulainen, T. (2009) (Toim.). Aikuiskoulutuksen vuosikirja: Tilastotietoja aikuisten opiskelusta 2007. Opetusministeriön julkaisuja 2009:42.

Lehikoinen, A., Saarniaho, R.\& Suikkanen, A. (2009). Oppimisella osallisuutta - vastauksia työn murrokseen. Helsinki:Sitra.

Lehtinen, E. (2004). Koulutusjärjestelmä suomalaisen yhteiskunnan muutoksessa. Teoksessa: Heiskala, R. (toim.) Artikkelikokoelma tutkimushankkeesta sosiaaliset innovaatiot, yhteiskunnan uudistumiskyky ja taloudellinen menestys. Helsinki: SITRA.

Lehtinen, E. \& Mielityinen, I. (2012). Selvitys henkilökohtaisista koulutustileistä: Soveltuvuus suomalaisen aikuiskoulutuksen rahoituksen uudistamiseksi. Väliraportti. Opetus- ja kulttuuriministeriön työryhmämuistioita ja selvityksiä 2012:12.
Lehtinen, E. \& Mielityinen, I. (2012). Selvitys henkilökohtaisista koulutustileistä: Ehdotukset ja vaikuttavuuden arviointi. Loppuraportti (Käsikirjoitus).

Lehtinen, E., Palonen, T., Tynjälä, P., Klemelä, K., Merenluoto, S., Pohjola, K. \& Veermans, K. (2012). Korkeakoulutettujen jatkokoulutuksen ja ehdotus järjestelmän kehittämiseksi - KYTKÖS-hanke. Opetus- ja kulttuuriministeriön julkaisuja 2012:22.

Education at a Glance 2012. OECD

Silvennoinen, H. \& Nori, H. (2012). Koulutuksen ja oppimisen marginaalissa. Käsikirjoitus. Ilmestyy Aikuiskasvatuksen 51. vuosikirjassa. 